Pamiętnik Literacki 2020, 1, s. 259-264

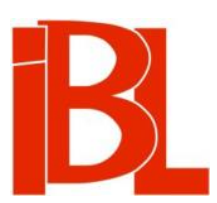

\title{
Józef Tomasz Pokrzywniak \\ (16 stycznia 1947 - 15 stycznia 2017)
}

Tomasz Chachulski 
$\begin{array}{lllllllllllllll}\text { 3. } & \mathrm{K} & \mathrm{R} & \mathrm{O} & \mathrm{N} & \mathrm{I} & \mathrm{K} & \mathrm{A} & - & \mathrm{Z} & \mathrm{M} & \mathrm{A} & \mathrm{R} & \mathrm{L} & \mathrm{I}\end{array}$

Pamiętnik Literacki CXI, 2020, z. 1, PL ISSN 0031-0514

DOI: $10.18318 / \mathrm{pl} .2020 .1 .17$

\section{JÓZEF TOMASZ POKRZYWNIAK (16 stycznia 1947 - 15 stycznia 2017)}

Pochodził z Czempinia - niewielkiej miejscowości w Wielkopolsce, położonej na południowy zachód od Poznania. Uczęszczał do liceum ogólnokształcącego w pobliskim Kościanie (1961-1965). Potem podją studia polonistyczne na Uniwersytecie im. Adama Mickiewicza w Poznaniu, które ukończył w 1970 roku z dyplomem magistra. Zaraz też rozpoczał pracę w Zakładzie Historii Kultury Polskiej w Instytucie Filologii Polskiej UAM na stanowisku asystenta - i chyba gdzieś od tego czasu datuje się jego głębokie zainteresowanie literatura polskiego oświecenia. Rozprawę doktorska (podobnie jak przedtem magisterium) napisał pod kierunkiem prof. Włodzimierza Dworzaczka, historyka, wybitnego specjalisty w zakresie genealogii, zajmującego się społeczeństwem pierwszej Rzeczypospolitej, wydawcy Liber generationis plebanorum (Liber chamorum) Waleriana Nekandy Trepki w prestiżowej serii „Biblioteka Pisarzów Polskich” (1963). Pod opieka profesora Pokrzywniak przygotował dysertację Jan Gorczyczewski - tłumacz, satyryk i krytyk, na jej podstawie uzyskał stopień naukowy doktora (1978), a w 3 lata później wydał rozprawę drukiem (1981). Gorczyczewski nie należał może do najwybitniejszych pisarzy stulecia XVIII i początku XIX wieku, zasługi tego twórcy dla Poznania i Wielkopolski były jednak znaczące. Pokrzywniak miał do satyryka sentyment i często o nim mówił przy różnych okazjach - chyba ostatni artykuł uczonego na ten temat: Jan Gorczyczewski - Wielkopolanin mało znany, ukazał się w miesięczniku „Kronika Miasta Poznania" (2006, nr 4).

W czasach Solidarności Pokrzywniak aktywnie uczestniczył w ruchu wielkich zmian. W latach 1980-1981 był redaktorem naczelnym miesięcznika „Środowisko”, wydawanego przez NSSZ „Solidarność” UAM.

W rok po uzyskaniu stopnia doktora został mianowany na stanowisko adiunkta i jego kariera akademicka potoczyła się zgodnie $\mathrm{z}$ obowiązującym $\mathrm{w}$ świecie naukowym rytmem. Stopień doktora habilitowanego nadano mu 19 XII 1994, podstawa przewodu była opublikowana wcześniej rozprawa Komedie Ignacego Krasickiego (Poznań 1994), tytuł profesorski przyznano Pokrzywniakowi 12 VII 1999, a w 2001 roku - objął stanowisko profesora zwyczajnego.

W macierzystej uczelni piastował wiele ważnych funkcji. W roku 1996 został członkiem Senatu UAM i uczestniczył w jego pracach do 2016 roku. Również w roku 1996 wybrano go na dwie kadencje na stanowisko dyrektora Instytutu Filologii Polskiej UAM. W latach 2005-2012 sprawował urzad dziekana Wydziału Filologii Polskiej i Klasycznej. W roku 2014 pełnił jeszcze obowiązki dziekana Wydziału Pedagogiczno-Artystycznego w Kaliszu. Zreszta przez wiele lat wykładał w Kaliszu i zawsze dobrze wspominał te spotkania ze studentami. 
Dla osób przyjeżdżających z zewnątrz jego działalność na Wydziale Filologii Polskiej i Klasycznej budziła podziw. Otoczony uznaniem i serdecznością współpracowników, był dla nich - jak można było sądzić - niekwestionowanym autorytetem. Dumny z osiagnięć swojego wydziału, jak prawdziwy gospodarz oprowadzał gości po reprezentacyjnym gmachu dawnej pruskiej Komisji Kolonizacyjnej przy ul. Fredry 10, wybudowanym na początku XX wieku. Dziekan pokazywał witraże umieszczone w ogromnych oknach głównego holu i klatki schodowej, przedstawiające najważniejszych polskich pisarzy, wyremontowaną salę obrad Rady Wydziału na najwyższym piętrze, nazywana Salonem Mickiewicza pod Kopułą, przestronne sale wykładowe i pokoje profesorskie, nowoczesną Bibliotekę Wydziału z salą teatralną im. Wojciecha Bogusławskiego, usytuowana na tyłach Collegium Maius. Biblioteka ta od 17 I 2018 nosi imię Profesora.

W środowisku polonistycznym prof. Pokrzywniak cieszył się powszechnym szacunkiem, wynikajacym zarówno $\mathrm{z}$ autorytetu naukowego, jak i cech charakteru: życzliwy, spokojny, wyważony, podejmował decyzje w sposób merytoryczny, dbając o interesy całego środowiska. Te same opinie powtarzały osoby współpracujace z Profesorem w Komitecie Badań Naukowych, w Komitecie Nauk o Literaturze PAN (był jego członkiem w latach 1996-2002), Komitecie Ewaluacji Jednostek i w wielu innych gremiach. W roku 2000 w Poznaniu doszło do pierwszego spotkania dyrektorów tych instytutów i wydziałów polonistycznych, które posiadały już certyfikat Uniwersyteckiej Komisji Akredytacyjnej przekształconej potem w Państwową Komisję Akredytacyjną ${ }^{1}$. Kolejne takie spotkanie odbyło się w następnym roku w Kazimierzu Dolnym nad Wisłą, w Domu Pracy Twórczej Katolickiego Uniwersytetu Lubelskiego, zwanym Rajchertówką. W ten sposób powstała Konferencja Dyrektorów Polonistyk Akredytowanych - niesformalizowane stowarzyszenie kierowników elitarnych ośrodków polonistycznych („urzędników” polonistycznych - jak mówił i pisał prof. Pokrzywniak), przekształcone w kilka lat później, w związku ze zmianami zasad przeprowadzania akredytacji, w Konferencję Dyrektorów Polonistyk Uniwersyteckich ${ }^{2}$. Prof. Pokrzywniak był współtwórca tej instytucji i jej pierwszym, wieloletnim przewodniczącym. Dbał o liczny udział przedstawicieli poszczególnych jednostek w obradach, o rangę Ogólnopolskiego Konkursu im. Czesława Zgorzelskiego na najlepszą pracę magisterską z zakresu filologii polskiej (w dwóch kategoriach: literaturoznawstwa i językoznawstwa), wspomagał zainicjowaną na KUL-u serię „Młoda Polonistyka”, w której wydawano rozprawy laureatów Konkursu Zgorzelskiego. Spotkania Konferencji Dyrektorów Polonistyk Uniwersyteckich służyły integracji środowiskowej, wymianie doświadczeń i opinii, dyskusjom na temat reform programowych, ale formułowano na nich także listy kierowane do Rady Głównej Szkolnictwa Wyższego, do Ministerstwa Nauki i Szkolnictwa Wyższego w sprawach: dwudyscyplinowości studiów (edukacji każdego przyszłego nauczyciela w zakresie dwóch dyscyplin), przekształcenia

1 Zob. J. T. P okrzywnia k, Od akredytacji do integracji. Konferencja Polonistyk Uniwersyteckich. W zb.: Przyszłość polonistyki. Koncepcje-rewizje-przemiany. Red. A. D zi a d e k, K. Kło s ińs ki, F. Mazurki ewicz. Katowice 2013, s. 343-346. 
5-letnich, jednolitych studiów magisterskich w dwustopniowe (licencjackie i magisterskie), standardów kształcenia dla filologii polskiej, zmian w specjalizacji nauczycielskiej, obniżenia punktacji za publikacje naukowe $z$ filologii polskiej, wprowadzenia krajowych ram kwalifikacji zapisu „specjalizacji” bądź „specjalności” na dyplomach polonistycznych i w wielu innych kwestiach, które przedstawiciele MNiSW tak hojnie zrzucali na środowiska akademickie, jakby nie zdając sobie

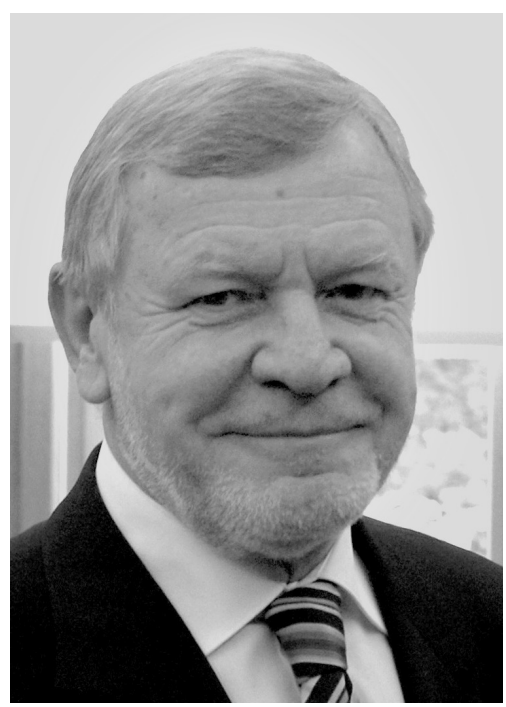

Józef Tomasz Pokrzywniak

sprawy z daleko idących konsekwencji permanentnych reform. Konferencja z powodzeniem wspópracowała $z$ innymi instytucjami reprezentującymi środowisko z Radą Główną Szkolnictwa Wyższego, Komitetem Nauk o Literaturze PAN i z Komitetem Językoznawstwa PAN. Przewodniczenie obradom przez prof. Pokrzywniaka pozwalało reprezentantom poszczególnych ośrodków zobaczyć te wszystkie problemy z dystansu, bez emocji, podjąć środki zaradcze, wypracować najlepsze decyzje, by przenieść je potem do konkretnych jednostek akademickich. Po pewnym czasie utarło się, że majowe spotkania organizowano w różnych uniwersytetach, jesienne - w Kazimierzu Dolnym nad Wisłą, w bezpośredniej bliskości KUL-u, na którym prowadzono sprawy organizacyjne Konferencji i wspomnianego Konkursu. Na uroczystych galach, odbywających się na KUL-u, na których wręczano nagrody laureatom Konkursu Zgorzelskiego, zawsze był obecny. Profesor potrafił nadać tym wszystkim spotkaniom niepowtarzalną atmosferę, np. te odbywające się w Kazimierzu Dolnym zostały utrwalone wieczornymi spacerami na rynek. To właśnie dzięki prof. Pokrzywniakowi Konferencja zyskała taką wysoką rangę, przynosząc - na różne sposoby - wymierny pożytek całemu środowisku polonistycznemu. I był Profesor zawsze obecny na uroczystej gali wręczenia nagród w tym konkursie, w Sali KUL. Wielokrotnie ubolewał nad „fatalnym w skutkach i ciągle 
trudnym do przezwyciężenia" podziałem filologów-polonistów na dwie różne dyscypliny: literaturoznawców i językoznawców ${ }^{3}$.

Przez wiele lat Profesor systematycznie współdziałał z Pracownią Oświecenia Instytutu Badań Literackich PAN, w latach 2006-2010 był członkiem z wyboru Rady Naukowej IBL PAN i w naturalny niejako sposób został później przewodniczacym rady cyfrowego „Biuletynu Polonistycznego” (po reaktywowaniu go w IBL) najważniejszego portalu polonistycznego w kraju i poza jego granicami. Przez cały czas swojej środowiskowej aktywności otaczał opieką autorów prac magisterskich i doktorskich, recenzował doktoraty, habilitacje, a po uzyskaniu tytułu naukowego - profesury. Dwukrotnie był także recenzentem doktoratów honoris causa - najbardziej prestiżowego $\mathrm{z}$ akademickich wyróżnień: Petera Brooka na UAM (2005) i Teresy Kostkiewiczowej na KUL-u (2011).

Zainteresowania naukowe prof. Pokrzywniaka od początku koncentrowały się wokół literatury polskiego oświecenia. W parze $\mathrm{z}$ nimi szedł ten szczególny rodzaj społecznego czy może raczej środowiskowego zaangażowania, tak dobrze widoczny w przedstawionych tu wcześniej rodzajach akademickiej aktywności. Wraz z Bożeną Chrząstowską i Marią Adamczyk był Pokrzywniak autorem podręcznika do I klasy liceum ogólnokształcącego Starożytność - oświecenie (wyd. 1: Warszawa 1987; ukazało się aż 14 edycji do 2000 roku $^{4}$ ), ponadto w serii „Biblioteka Polonistyki” opublikował książkę Ignacy Krasicki (1992), pisał do wspomnianej już „Kroniki Miasta Poznania”, wielokrotnie brał udział w poznańskich i ogólnopolskich dyskusjach, panelach poświęconych sytuacji polonistyki, nauk humanistycznych i środowiska akademickiego w ogóle, był uczestnikiem kongresów, konferencji, zjazdów polonistycznych. Należał także do Poznańskiego Towarzystwa Przyjaciół Nauk, Towarzystwa Literackiego im. Adama Mickiewicza i Polskiego Towarzystwa Badań nad Wiekiem Osiemnastym oraz do Towarzystwa Naukowego im. Wojciecha Kętrzyńskiego w Olsztynie.

Mimo tak licznych, trwających latami obowiązków organizacyjnych i funkcji prof. Pokrzywniak nieustannie pracował naukowo. Pisał o większości spośród oświeceniowych twórców: o Stanisławie Trembeckim, Adamie Naruszewiczu, Franciszku Karpińskim, Franciszku Dionizym Kniaźninie, Michale Dymitrze Krajewskim, Gracjanie Piotrowskim, Józefie Wybickim. „Jego” pisarzem był jednak przede wszystkim Krasicki. Poświęcił mu wiele czasu i uwagi naukowej. Poza wspomnianą książką o charakterze popularnonaukowym (drugie podobne wydanie ukazało się $\mathrm{w}$ oficynie „Rebis” w 1995 roku) napisał świetny wstęp do edycji Satyr i listów (Wrocław 1988, 1999) w opracowaniu Zbigniewa Golińskiego („Biblioteka Narodowa” seria I, nr 169), przygotował do druku tom zawierający wszystkie Komedie Krasickiego (Poznań 2016) do wydania krytycznego Dzieł zebranych tego pisarza, pod redakcją Golińskiego,

Ibidem, s. 346.

Korzystam $\mathrm{z}$ informacji zawartych w ważnym i świetnie udokumentowanym artykule: B. J u dk o w i a k, K. M ell e r, Wspomnienie o naszym Profesorze: Tomasz Pokrzywniak. „Dobrze było z Nim być”. „Życie Uniwersyteckie” [UAM] Poznań 2017, nr 1. Przedruk w: Józef Tomasz Pokrzywniak (1947-2017) - nasz profesor. „Filologia Polska. Roczniki naukowe Uniwersytetu Zielonogórskiego” 2018, z. 4. Na stronie: https://zbc.uz.zgora.pl/dlibra/publication/59680/edition/51281/content?ref=desc (data dostępu: 31 I 2020). Pokrzywniak był członkiem Rady Naukowej Roczników. 
a po jego śmierci w 2008 roku doprowadził do wznowienia zatrzymanych na wiele lat prac nad edycją, uzyskując na ten cel grant z Narodowego Programu Rozwoju Humanistyki oraz sam przejął i kontynuował redakcję tych dzieł. Niemałe znaczenie maja też rozsiane po tomach zbiorowych artykuły o Krasickim: o jego związkach z Lidzbarkiem Warmińskim, o kobietach w utworach XBW, o jego stosunku do insurekcji kościuszkowskiej, o Mikołaja Doświadczyńskiego przypadkach, o Myszeidzie, o treściach religijnych $\mathrm{w}$ pisarstwie XBW.

Ostatnią książka Profesora była monografia Ignacy Krasicki wśród pisarzy oświecenia (Poznań 2015), zbierająca rozproszone wcześniej rozprawy. Część pierwsza miała charakter generalizujący: pokazywała pisarzy polskiego oświecenia Z perspektywy 200 lat recepcji i w opiniach Adama Mickiewicza - wykładowcy Collège de France. W części drugiej znalazły się prace dotyczące samego Krasickiego, tworzące summę rozpoznań prof. Pokrzywniaka, a zarazem portret XBW ugruntowany podczas wielu lat badań, kiedy to stopniowo uczony wchodzi w szczególny rodzaj bliskości z poetą, o którym pisze. Jak nikt inny Profesor rozumiał jego wybory i motywacje, powściągliwość deklaracji światopoglądowych przy żelaznym trzymaniu się raz wybranych wartości, pozorny sybarytyzm, skrywający nieustanny wysiłek myśli i niebywała pracowitość, mądrość i odwagę politycznych wyborów, pozwalających bez koniunkturalnych ustępstw uzyskać maksimum pożytku dla swojego środowiska. Jest to portret napisany z humorem, a zarazem wnikliwy i głęboko sięgający do rzeczywistych sensów spuścizny Księcia Biskupa, wskazujący trwałość stereotypów recepcji, ale i siłę oddziaływania wielu jego drobnych utworów, na zawsze już osadzonych w polskiej pamięci zbiorowej. Jeśli dodamy do tej charakterystyki zasadę umiaru, „złotego środka”, optymizm poznawczy, ufność i otwartość wobec innych, otrzymamy jednocześnie wszechstronne podsumowanie badań prof. Pokrzywniaka nad Krasickim oraz jego epoka - i w pewnej mierze zwierciadlany autoportret Uczonego, który w pisarzach sprzed dwóch stuleci najlepiej dostrzegał to, co dla niego samego było najważniejsze ${ }^{5}$.

Józef Tomasz Pokrzywniak uczestniczył niemal we wszystkich spotkaniach naukowych badaczy literatury polskiego oświecenia - przyjeżdżał z referatami na kongresy oświeceniowe do Wrocławia i Krakowa, na konferencje organizowane w IBL PAN, na Czytanie Kniaźnina do Zakopanego (2010), na grantowe konferencje poświęcone „Czytaniu poetów polskiego oświecenia” (2013-2015). Ostatnia z nich, dotycząca Karpińskiego, została przeprowadzona w Klewinowie na Podlasiu, wsi nieopodal Białegostoku, w maju 2016. Profesor musiał wyjechać wcześniej - służbowe sprawy wzywały go do Poznania. Żegnaliśmy go wspólnie, stojąc gromadą przed budynkiem wśród drzew $z$ widokiem na rozległe pola, a Tomasz Pokrzywniak, uśmiechając się jak zawsze serdecznie do wszystkich, odjeżdżał swoim samochodem w długą droge do Poznania. Na III Kongresie Badaczy Osiemnastego Wieku, który odbywał się w tym mieście w dniach 15-17 IX 2016, Profesor pojawił się tylko na

5 Zob. informacje, uwagi i opinie zawarte w zbiorze Złoty środek. Literatura wobec rozterek, niepokoju i poszukiwania równowagi. Studia poświęcone pamięci Profesora Józefa Tomasza Pokrzywniaka (Red. nauk. G. Ra ub o, K. Trybuś. Poznań 2017). Szczególnie istotne są tu prace G. Ra u by i K. Trybusia Wprowadzenie. Wdzięczność i pamięć oraz V. Szos tak - I właśnie ktoś taki nam teraz odszedt. 
chwilę. Był już bardzo chory. Jego pogrzeb zgromadził dużą część badaczy oświecenia, przyjaciół i współpracowników Profesora, którzy - po uroczystościach - wspominali go na wieczornym spotkaniu Jemu poświęconym.

\section{Tomasz Chachulski}

Uniwersytet Kardynała Stefana Wyszyńskiego, Warszawa - Cardinal Wyszyński University, Warsaw

ORCID: 0000-0001-7449-8022

Abstract

OBITUARY: JÓZEF TOMASZ POKRZYWNIAK (January $16^{\text {th }}, 1947-J a n u a r y ~ 15^{\text {th }}, 2017$ )

The paper is a remembrance text about professor Józef Tomasz Pokrzywniak, a distinguished scholar specialising in the Polish Enlightenment literature, especially in Ignacy Krasicki's and Jan Gorczyczewski's creativity, Adam Mickiewicz University of Poznań employee, Dean of the Faculty of Polish and Classical Philology, Adam Mickiewicz University of Poznań. Professor Józef Tomasz Pokrzywniak was a member of many institutions that linked scholars and Polish teaching organisers all along Poland. 